\title{
Spatial Buffering of $\mathbf{K}^{+}$by the Retinal Pigment Epithelium in Frog
}

\author{
Joe Immel and Roy H. Steinberg \\ Departments of Physiology and Ophthalmology, University of California, San Francisco, California 94143
}

Using $\mathrm{K}^{+}$-specific microelectrodes in the isolated retinal pigment epithelium preparation from frog eye, we have examined changes in extracellular $K^{+}$in the unstirred layer between the choroid and basal membrane. We found, using agents to depolarize apical and basal membranes, that membrane potential modulates $\mathrm{K}^{+}$efflux from the basal membrane into the choroid.

$\left[\mathrm{K}^{+}\right]$in the choroid was found to be higher than in the bathing medium. From the basal (scleral) surface of the choroid to the basal membrane of the retinal pigment epithelium, $\left[\mathrm{K}^{+}\right]$increased from $2 \mathrm{~mm}$ (bath concentration) to an average of $\mathbf{2 . 8 4}$ mM near the basal membrane. When $\left[\mathrm{K}^{+}\right]$was increased on the apical side, epithelial membranes depolarized and produced $\left[\mathrm{K}^{+}\right]$ efflux from the basal membrane that led to an increase in choroidal $\left[\mathrm{K}^{+}\right]$. $\mathrm{Ba}^{2+}, 2 \mathrm{mM}$, ouabain, $0.1 \mathrm{~mm}$, also evoked increases in choroidal $\left[\mathrm{K}^{+}\right]$concomitant with membrane depolarization. Thus, apical $\mathrm{Na}^{+} / \mathrm{K}^{+}$pump transport and $\mathrm{K}^{+}$leakage due to tissue damage were eliminated as possible sources of observed increases in choroidal $\left[\mathrm{K}^{+}\right]$since apical $\mathrm{Ba}^{2+}$ and ouabain depolarize epithelial membranes without increasing apical $\left[\mathrm{K}^{+}\right]$. The effects of depolarizing agents were blocked by basal $\mathrm{Ba}^{2+}$, demonstrating the requirement for a large $\mathbf{K}^{+}$conductance at the basal membrane. Theoretical analysis shows that shunt resistance and isolation of apical and basal compartments are limiting factors in the transfer of $\mathrm{K}^{+}$. In the retinal pigment epithelium, shunt resistance favors the transfer of electrical potentials between membranes while the paracellular pathway selectively impedes movement of $\mathrm{K}^{+}$between compartments.

We conclude that $\left[\mathrm{K}^{+}\right]$changes in the apical (retinal) compartment are transferred to the basal compartment (choroid) by $\mathrm{K}^{+}$spatial buffering. By this mechanism, $\left[\mathrm{K}^{+}\right]$changes are electrically translated from one side to the other independently of the apical $\mathrm{Na}^{+} / \mathrm{K}^{+}$pump or other active mechanisms.

Neuronal activity in the CNS releases $\mathrm{K}^{+}$which, if allowed to accumulate, depolarizes surrounding cells and disrupts nervous function (Frankenhaeuser and Hodgkin, 1956; Somjen, 1979). Kuffler and his colleagues suggested how depolarizing the glial cell membrane potential by $\mathrm{K}^{+}$entry into the cell could release $\mathrm{K}^{+}$into regions of lower concentration-a process they termed spatial buffering (Kuffler, 1967; Orkand et al., 1966). This transcellular movement of $\mathrm{K}^{+}$has been shown to be more efficient than simple extracellular diffusion in vertebrate brain (GardnerMedwin, 1982) and drone retina (Coles and Orkand, 1983). In Müller cells isolated from vertebrate retina, spatial buffering occurs rapidly, with little delay between $\mathrm{K}^{+}$entry at the distal end and exit from the proximal end-foot (Newman, 1984; Newman et al., 1984).

The retinal pigment epithelium (RPE) lies at the back of the

Received Dec. 13, 1985; revised Apr. 7, 1986; accepted Apr. 17, 1986.

Supported in part by NIH Research Grant EX-01429 (R.H.S.) and Research Fellowship EY-05710 (J.I.) from the National Eye Institute.

Correspondence should be addressed to Joe Immel, Department of Physiology, S-762, University of California, San Francisco, CA 94143.

Copyright (C) 1986 Society for Neuroscience $0270-6474 / 86 / 113197-08 \$ 02.00 / 0$ eye and separates the neural retina from its choroidal blood supply. Junctional complexes form a tight, high-resistance barrier and interconnect the monolayer of hexagonal cells. Microvilli, which cover the apical surface, extend into the subretinal space, interdigitating with the photoreceptor outer segments. The apical and basal membranes of the RPE also have different ionic and transport properties and are electrically isolated to some degree by the high-resistance junctions between them (Miller and Steinherg, 1977a; Miller et al., 1978; Steinberg and Miller, 1979). The anatomical and physiological properties of RPE cells suggest that they could act as $\mathrm{K}^{+}$spatial buffers. Both the apical and basal membranes are permeable to $\mathrm{K}^{+}$(the basal almost exclusively so in frog), and the cells respond robustly to changes in subretinal [K+]。 (Miller and Steinberg, 1977a; Oakley, 1977; Oakley et al., 1977). In vivo light-evoked photoreceptor activity causes a decrease in $\mathrm{K}^{+}$concentration in the subretinal space between the photoreceptor outer segments and the apical face of the RPE (apical $\left[\mathrm{K}^{+}\right]_{0}$ ). With prolonged illumination, apical $\left[\mathrm{K}^{+}\right]_{\mathrm{o}}$ levels partially recover and subsequently overshoot with onset of darkness to produce $\left[\mathrm{K}^{+}\right]_{0}$ levels greater than resting dark levels (Oakley and Steinberg, 1982; Steinberg et al., 1980). This paper examines the hypothesis that subretinal $\mathrm{K}^{+}$ fluctuations can be buffered by the RPE. This mechanism would work in the following way. An increase in $\left[\mathrm{K}^{+}\right]_{0}$ at the apical membrane would lead to a net movement of $\mathrm{K}^{+}$into the cell depolarizing the apical membrane potential. The basal membrane also depolarizes due to the electrical coupling of the membranes. This, in turn, reduces the inward (electrical) driving force on $\mathrm{K}^{+}$at the basal membrane but leaves the outward (chemical) driving force unchanged. Thus, there is an increase in $\mathrm{K}^{+}$efflux from the basal membrane. In this way, a $\left[\mathrm{K}^{+}\right]_{\text {o }}$ change in one compartment translates into a $\left[\mathrm{K}^{+}\right]_{0}$ change in the other.

To test this hypothesis, we measured $\left[\mathrm{K}^{+}\right]_{0}$ levels with $\mathrm{K}^{+}$specific microelectrodes placed in the choroid near the RPE basal membrane. In this experimental system, the choroidal milieu consists of an unstirred layer that exchanges slowly with the bathing medium. We expected, then, that increases in $\mathrm{K}^{+}$ efflux from the basal membrane should cause increases in choroidal $\mathrm{K}^{+}$concentration $\left(\left[\mathrm{K}^{+}\right]_{\mathrm{C}}\right)$. Our findings show that treatments that depolarize RPE membranes increase $\left[\mathrm{K}^{+}\right]_{\mathrm{C}}$ and those that hyperpolarize these membranes decrease $\left[\mathrm{K}^{+}\right]_{\mathrm{C}}$.

\section{Materials and Methods}

All experiments were performed on bullfrog (Rana catesbeiana) RPEchoroid preparations. The technique for dissection and the apparatus for mounting and perfusing the tissue have been previously described (Miller and Steinberg, 1977a). Briefly, frogs were dark-adapted overnight and the eyes excised under dim red light in order to detach the retina easily. The retina was removed from sections of the posterior half of the eye, and small, approximately $5 \mathrm{~mm}^{2}$, pieces of RPE-choroid were dissected free of the sclera and mounted in a plastic holder. The holder differed slightly from that used by Miller and Steinberg (1977a) and Hughes et al. (1984) in that a 5-mm-diameter disk of nylon mesh with $44 \%$ open area supported the tissue in an indentation in the top of the holder. A circular ridge on the bottom portion of the holder sealed the edges of the tissue, which was sandwiched between the 2 halves. 


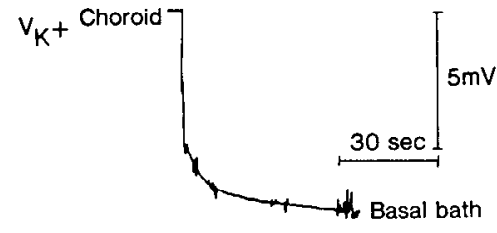

Figure 1. Determination of $\left[\mathrm{K}^{+}\right]_{\mathrm{C}}$ levels. The $\mathrm{K}^{+}$-sensitive electrode was advanced through the choroid to a point near the basal membrane. This $V_{\mathrm{K}^{+}}$record shows the result of rapidly pulling the electrode out of the choroid into the basal bath containing $2 \mathrm{mM} \mathrm{K}^{+}$. The drop in $V_{\mathrm{K}^{+}}$ was $7.7 \mathrm{mV}$, corresponding to a change in $\left[\mathrm{K}^{+}\right]$from 2.6 to $2.0 \mathrm{mM}$. In 20 experiments of this type, the average level of $\left[\mathrm{K}^{+}\right]_{\mathrm{C}}$ was $2.84 \mathrm{~mm}$ ( $10.52 \mathrm{SD})$.

The tissue was mounted with the basal side up and the $\mathrm{K}^{+}$-sensitive microelectrode penetrated the choroid after passing between the threads of the mesh. This method allows access to the choroid and basal membrane without disrupting the integrity of the RPE, which might produce artifactual leakage across the tissue. In experiments using an intracellular microelectrode in conjunction with the $\mathrm{K}^{+}$-sensitive microelectrode, the tissue was approached from the apical side with the mesh on the back side of the tissue, so that the choroid was accessed through the RPE.

Both sides of the preparation were superfused with a modified Ringer's solution at a rate of $5-7 \mathrm{ml} / \mathrm{min}$. The area of the tissue exposed to the solution was $0.07 \mathrm{~cm}^{2}$. The normal perfusate $(\mathrm{pH} \mathrm{7.4)}$ was composed of $\mathrm{NaCl}(82.5 \mathrm{~mm}), \mathrm{NaHCO}_{3}(27.5 \mathrm{~mm}), \mathrm{KCl}(2.0 \mathrm{~mm}), \mathrm{CaCl}_{2}(1.8 \mathrm{~mm})$, $\mathrm{MgCl}_{2}(1.0 \mathrm{~mm})$, and glucose $(10.0 \mathrm{mM})$. Solutions were constantly bubbled with $95 \% \mathrm{O}_{2} / 5 \% \mathrm{CO}_{2}$ gas. Experimental solutions were made by equimolar replacement of $\mathrm{NaCl}$ with test chemicals.

\section{Electrodes}

For intracellular recording of RPE membrane potential, microelectrodes were constructed from $1.0 \mathrm{~mm}$ glass tubing (Omega Dot Glass Co.), filled with $5 \mathrm{M}$ potassium acetate and beveled to a resistance of $60-80$ $\mathrm{M} \Omega$.

Double-barreled, $\mathrm{K}^{+}$-specific microelectrodes used to measure extracellular $\mathrm{K}^{+}$concentrations were constructed as described in detail by Oakley (1977). One barrel was filled with Corning $477317 \mathrm{~K}^{+}$exchanger (Corning Science Products Div.), while the reference barrel was filled with $5 \mathrm{M} \mathrm{LiCl} . \mathrm{K}^{+}$-specific microelectrodes were beveled slightly to give tip diameters from less than 1 to $2 \mu \mathrm{m}$. The potential difference between the reference and $\mathrm{K}^{+}$barrels is a function of the logarithm of $\left[\mathrm{K}^{+}\right]_{\mathrm{o}}$. Electrodes were calibrated in solutions of varying $\mathrm{K}^{+}$concentrations with a constant value of $\left[\mathrm{K}^{+}\right]+\left[\mathrm{Na}^{+}\right]$(Oakley, 1977; Walker, 1971).

\section{Measurement of $\left[\mathrm{K}^{+}\right]_{c}$}

The choroidal $\mathrm{K}^{+}$concentration, $\left[\mathrm{K}^{+}\right]_{\mathrm{C}}$, was determined by rapidly withdrawing the $\mathrm{K}^{+}$-sensitive microelectrode after $V_{\mathrm{K}^{+}}$had stabilized. For basal approaches ( $n=16$; through the choroid), the electrode was advanced as far as possible into the choroid without penetrating the RPE. Current pulses passed across the tissue and measured with the reference barrel of the electrode were used to measure tissue resistance near the electrode tip. A decrease in resistance of more than $10 \%$ was taken as an indication that the RPE had becn picrecd. For apical approaches $(n=4)$, the site of penetration was considered sealed if $(1)$ a large increase in resistance was measured at the electrode tip, and (2) a 2-5 mM apical $\left[\mathrm{K}^{+}\right]_{0}$ change produced a change in $V_{\mathrm{K}^{+}}$similar in magnitude and time course to basal penetrations.

It was not possible to determine accurately the absolute depth of penetration into the choroid. Very often the tissue moved visibly with the advance of the electrode. This resulted in a wide variability in baseline $\left[\mathrm{K}^{+}\right]_{r}$ levels and $V_{\mathrm{K}^{+}}$responses to apical changes. Generally, the electrode was advanced from the basal side until there was sufficient response of $V_{\mathrm{K}^{+}}$to a 2-5 mM change in apical $\left[\mathrm{K}^{+}\right]_{0}$. Further advance often led to an apparent elastic rebound of the tissue that thrust the electrode tip through the RPE into the apical bath. At this point, tissues usually showed signs of local leakage even if the electrode was moved back into the choroid. When this occurred, the electrode was retracted and the choroid was penetrated at a different site.

Sometimes, in the course of choroidal penetrations, there occurred a slight drop in transepithelial resistance $(<10 \%)$ measured on the reference barrel of the $\mathrm{K}^{+}$-sensitive electrode. This usually signaled a location close to the basal membrane since $V_{K^{+}}$responses to a $2-5 \mathrm{mM}$
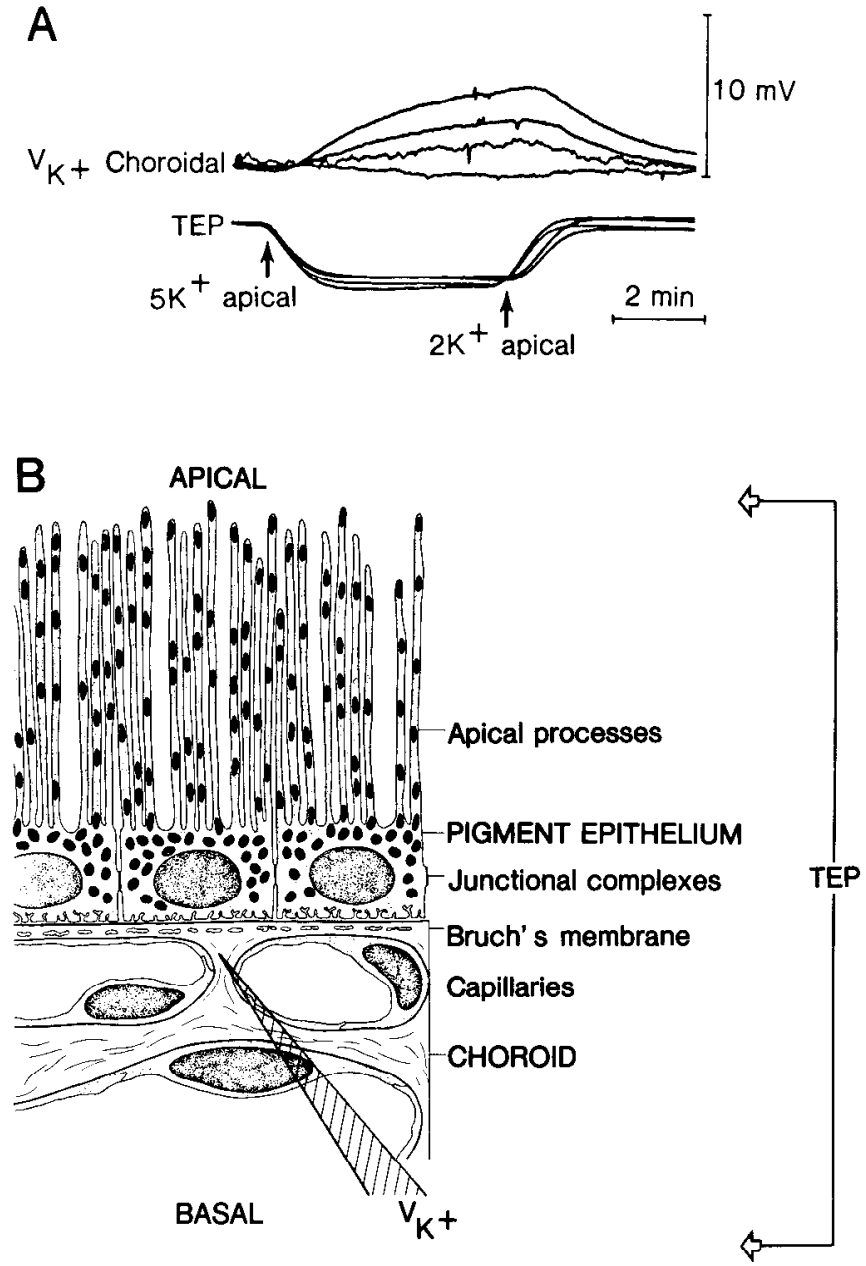

Figure 2. A, Size of $V_{\mathrm{K}^{+}}$response versus depth in choroid. The $\mathrm{K}^{+}$ sensitive clectrode was advanced into the choroid from the outer (basal) surface towards the basal membrane. At 4 positions along the way, apical $\left[\mathrm{K}^{+}\right]_{\text {。 }}$ was increased from 2 to $5 \mathrm{~mm}$ and then returned. Corresponding changes in $V_{\mathrm{K}^{+}}$(upper) and TEP (lower) are shown for each location. Although each of the traces probably started at a different baseline level of $\left[\mathrm{K}^{+}\right]_{\mathrm{C}}$, they have been superimposed at the beginning in order to compare amplitudes. The lower $V_{\mathrm{K}^{+}}$trace is from the outer surface of the choroid. The amplitude of the traces increased with increasing depth in the choroid; i.e., the largest response was from the deepest location, nearest the basal membrane. TEP traces were also superimposed. Differences in TEP responses at offset of the stimulus (5 to $2 \mathrm{mM} \mathrm{K}^{+}$) are due to slightly different time courses. $B$. Schematic diagram of the RPE-choroid preparation. The transepithelial potential (TEP, as shown above in $A$ ) is measured across the tissue from the apical to the basal bath. For most $V_{\mathrm{K}^{+}}$measurements, a doublc-barrcled ionselective microelectrode was passed through the choroid to a point near the RPE basal membrane. For measurements of $V_{\text {ap }}$ and $V_{\text {ba }}$, RPE cells were impaled from the apical side by a microelectrode. The intracellular potential was referenced to the basal bath for $V_{\mathrm{ba}}$ and apical bath for $V_{\text {ap }}$ (see Fig. 3).

apical $\left[\mathrm{K}^{+}\right]_{\circ}$ change were relatively large and fast. Further penetration would usually produce an abrupt decrease in transepithelial resistance and a large increase in $V_{\mathrm{K}^{+}}$indicating that the RPE had been penetrated.

Baseline $\left[\mathrm{K}^{+}\right]_{\mathrm{C}}$ measurements may have been influenced by the time elapsed after dissection of the tissue. After several hours, high values of $\left[\mathrm{K}^{+}\right]_{\mathrm{C}}$ were not found. We presume that this is due to gradual degradation of the tissue.

In some experiments, a small amount of unidirectional drift was sometimes observed in $V_{\mathrm{K}^{+}}$records. In order to remove this artifact, the slope of the drift was determined for 5-10 min before experimental procedures. A line of this slope was then digitally subtracted from the records. 

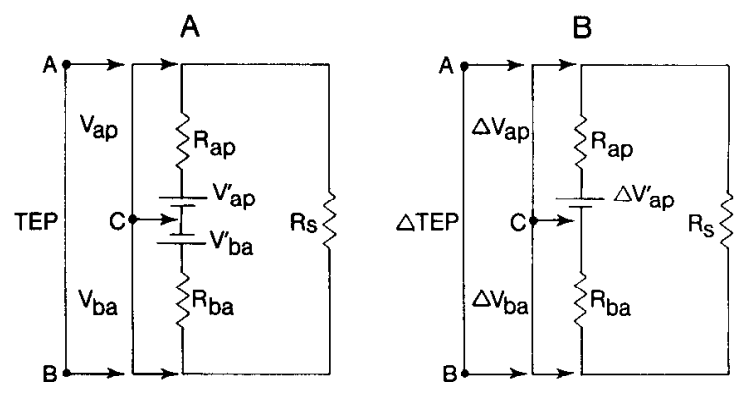

Figure 3. Electrical schematic representation of the RPE (after Griff and Steinberg, 1984). A, Intracellular electrode at point $C$ mcasurcs an apical membrane potential $\left(V_{\mathrm{ap}}\right)$ created by the apical ionic potential $\left(V_{\mathrm{ap}}^{\prime}\right)$ across the apical membrane resistance $\left(R_{\mathrm{ap}}\right)$ when referenced to point $A$. The electrode when referenced to point $B$ measures the basal membrane potential $\left(V_{\mathrm{ba}}\right)$, the result of the basal ionic potential $\left(V_{\mathrm{ba}}\right)$ across the basal membrane resistance $\left(R_{b}\right)$. The membranes are connected via the paracellular pathway through the shunt resistance $\left(R_{\mathrm{s}}\right)$. The transepithelial potential $(T E P)$ is the difference between $V_{\mathrm{ap}}$ and $V_{\mathrm{ba}}$ measured by electrodes in the apical and basal baths. $B$, Result of changing the apical membrane potential. Changing the apical membrane potential is analogous to creating a new ionic battery $\left(\Delta V_{\text {ap }}\right)$ on the apical membrane. (The other batteries have been omitted.) The result will be a change in both membrane potentials $\left(\Delta V_{\mathrm{ap}}\right.$ and $\left.\Delta V_{\mathrm{ba}}\right)$ and TEP ( $\triangle \mathrm{TEP})$.

\section{Results}

\section{Measurement of $\left[\mathrm{K}^{+}\right]$}

The choroid impedes the diffusion of solutes between the basal bath and the basal membrane of the RPE (Miller and Steinberg, 1977a). Thus, $\mathrm{K}^{+}$, which is transported transepithelially from the apical to the basal side of the RPE, may concentrate in the choroid near the RPE basal membrane (Miller and Steinberg, 1982). To test this possibility $\mathrm{K}^{+}$-sensitive microelectrodes were inserted into the choroid. After $V_{\mathrm{K}^{+}}$had stabilized upon penetration of the choroid, the electrodes were rapidly withdrawn into the basal bath (Fig. 1). The decrease in $V_{\mathrm{K}^{+}}$that occurred after withdrawal indicated a higher $\mathrm{K}^{+}$concentration in the choroid than in the bathing medium. In 20 such withdrawal experiments the average level of $\left[\mathrm{K}^{+}\right]_{\mathrm{C}}$ was $2.84 \mathrm{mM}(\mathrm{SD}=0.52)$, ranging from 2.3 to $3.9 \mathrm{~mm}$ when the bathing solution contained $2 \mathrm{mM}\left[\mathrm{K}^{+}\right]_{\mathrm{o}}$.

The rather wide range of values reflects differing depths of penetration into the choroid. Figure $2 A$ demonstrates the relationship between depth in the choroid and the magnitude of $V_{\mathrm{K}^{+}}$responses evoked by a $2-5 \mathrm{~mm}$ increase in apical $\left[\mathrm{K}^{+}\right]_{0}$. Although each trace started from a different baseline $\left[\mathrm{K}^{+}\right]_{\mathrm{c}}$, they were superimposed at the beginning in order to compare the relative response magnitudes. The bottom trace, taken at the basal surface of the choroid, showed a very small increase of $V_{\mathrm{K}^{+}}$, while the top trace, from deep in the choroid near the basal membrane, showed the largest deflection. As the electrode was advanced into the choroid, the amplitude of the response increased.' Figure $2 B$ shows the locations of electrodes used to record traces shown in Figure $2 A$.

\section{Measurement of RPE membrane potentials}

Theory. The electrical parameters and behavior of the RPE have been previously analyzed in detail, and the reader is referred to

\footnotetext{
It was not possible to demonstrate clearly an increase of $\left[\mathrm{K}^{+}\right]_{\mathrm{C}}$ as the depth of penetration increased because of fluctuations that occurred as the electrode either encountered obstacles or penetrated cells in the choroid (e.g., melanocytes, collagen, blood vessels, etc.). Baseline values of $\left[\mathrm{K}^{+}\right]_{\mathrm{C}}$ varied greatly from position to position, sometimes even dropping as the electrode was moved through regions of differing $\left[\mathrm{K}^{+}\right]_{\mathrm{C}}$. Although $\left[\mathrm{K}^{+}\right]_{\mathrm{C}}$ could drop from one region to another in the choroid, it was always greater than that of the bath, as shown by the withdrawal experiments.
}
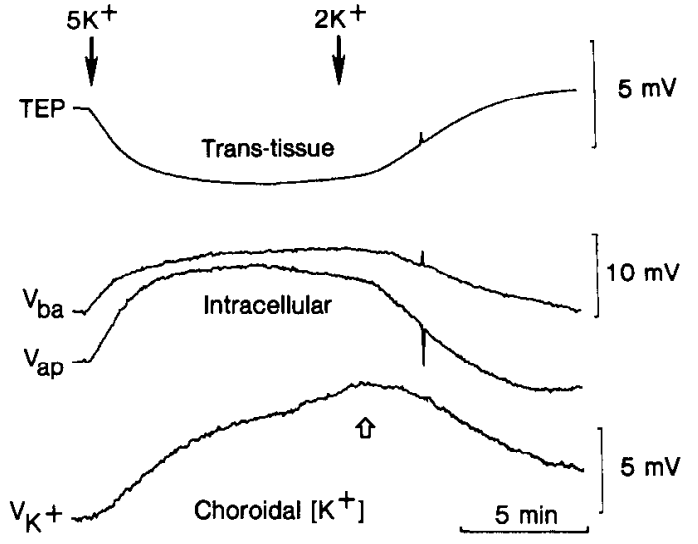

Figure 4. Effect of changing apical $\mathrm{K}^{+}$. In this experiment, the RPE was approached from the apical side. An intraccllular microclectrode was placed in an RPE cell and a $\mathrm{K}^{+}$-sensitive electrode placed in the choroid. When apical $\left[\mathrm{K}^{+}\right]_{\mathrm{o}}$ was increased from 2 to $5 \mathrm{~mm}, V_{\mathrm{ap}}$ depolarized $11.1 \mathrm{mV}$ and TEP dropped $3.5 \mathrm{mV}$ (from 10.4 to $6.9 \mathrm{mV}$ ) due to a decrease in the difference between $V_{\mathrm{ap}}$ and $V_{\mathrm{ba}}$. The level of $\left[\mathrm{K}^{+}\right]_{\mathrm{c}}$ also increased as indicated by the increase in $V_{\mathrm{K}+}$. [The small additional rise in $V_{\mathrm{K}^{+}}$(open arrow) was due to a disturbance during replenishment of the bathing solutions.]

relevant papers for a complete discussion of theory (Linsenmeier and Steinberg, 1982; Miller and Steinberg, 1977a). The following analysis is a brief summary describing electrical changes that occur in these experiments. To test the spatial buffering hypothesis, we employed agents that depolarized RPE membrane potentials. Applied to the apical side, these agents produced changes in the apical membrane potential $\left(V_{\mathrm{ap}}\right)$ that were transmitted (shunted) to the basal membrane and produced attenuated changes in the basal membrane potential, $V_{\text {ba }}$ (Boulpaep, 1971). The mechanism can be understood with the use of the schematic in Figure $3 A$ (Griff and Steinberg, 1984). The apical and basal membranes, represented in Figurc $3 A$ by $R_{\text {a }}$ and $R_{\text {ba }}$, are connected through the shunt resistance, $R_{\mathrm{s}}$. The RPE membrane potentials are generated by batteries on each membrane, $V_{\text {ap }}^{\prime}$ and $V^{\prime}{ }_{\text {ba }}$, with the apical membrane potential more hyperpolarized than the basal (Miller and Steinberg, 1977a). When measured with an intracellular microelectrode, the potential across the apical membrane $\left(V_{\mathrm{ap}}\right)$ is about $-90 \mathrm{mV}$ and that across the basal membrane $\left(V_{\mathrm{ba}}\right)$ is $-80 \mathrm{mV}$. Since these potentials are dissimilar, current flows away from the apical membrane, across $R_{\mathrm{s}}$, and into the basal membrane. This movement of current through the shunt in the apical to basal direction makes $V_{\text {ap }}$ smaller than $V_{\text {ap }}^{\prime}$; at the same time, there is a gain on the basal side, making $V_{\mathrm{ba}}$ larger than $V_{\mathrm{ba}}^{\prime}$. Therefore, the measured potentials are (from Miller and Steinberg, 1977a)

$$
\begin{aligned}
& V_{\mathrm{ap}}=V_{\mathrm{ap}}^{\prime}-i_{\mathrm{s}} R_{\mathrm{ap}} \\
& V_{\mathrm{ba}}=V_{\mathrm{ba}}^{\prime}+i_{\mathrm{s}} R_{\mathrm{ba}}
\end{aligned}
$$

where $i_{\mathrm{s}}$ is the shunt current given by

$$
i_{\mathrm{s}}=\left(V_{\mathrm{ap}}^{\prime}-V_{\mathrm{ba}}^{\prime}\right) /\left(R_{\mathrm{ap}}+R_{\mathrm{s}}+R_{\mathrm{ba}}\right)
$$

The difference between $V_{\mathrm{ap}}$ and $V_{\mathrm{ba}}$ also generates a potential across the shunt resistance, the transepithelial potential (TEP), that can be measured by placing electrodes on each side of the tissue. Thus, with the terms arranged to yield a normally positive TEP, we find

$$
\mathrm{TEP}=V_{\mathrm{ba}}-V_{\mathrm{ap}}
$$

Changing the apical membrane potential in these experiments is equivalent to producing a new battery $\left(\Delta V_{\text {an }}^{\prime}\right)$ at the apical 
A

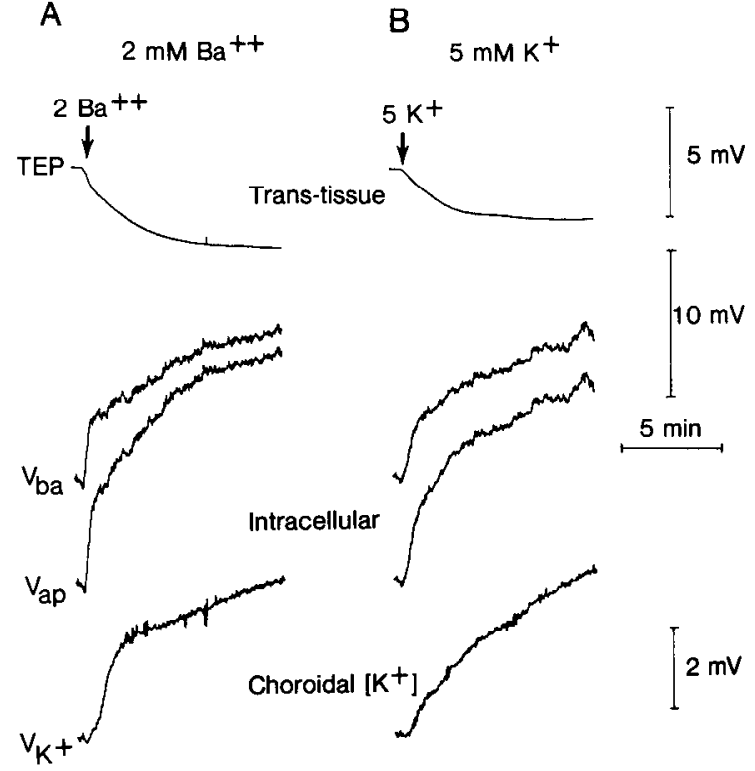

Figure 5. Effects of apical $\mathrm{Ba}^{2+}$ and increased $\left[\mathrm{K}^{+}\right]_{0}$ compared in the same cell. The RPE was approached from the apical side; an intracellular microelectrode was placed in an RPE cell and a $\mathrm{K}^{+}$-sensitive microelectrode placed in the choroid. $A$, In the traces on the left-hand side, $2 \mathrm{~mm}$ $\mathrm{Ba}^{2+}$ was added to the apical solution. $\mathrm{Ba}^{2+}$ caused a decrease in TEP hy depolarizing $V_{\text {ap }}$ (middle traces). As a result of shunting, the basal membrane also depolarized. The difference in the amount of depolarization from the apical to the basal membrane determined the size of the TEP change (top). $\left[\mathrm{K}^{+}\right]_{\mathrm{C}}$ increased with the depolarization of the apical membrane, as shown by the increase in $V_{\mathrm{K}^{+}}($bottom). $B$, In the same cell (prior to the addition of $\mathrm{Ba}^{2+}$ ) increased apical $\left[\mathrm{K}^{+}\right]_{0}$ caused similar changes in TEP and membrane potentials, producing a similar increase in $\left[\mathrm{K}^{+}\right]_{\mathrm{C}}$.

side of the circuit. Considering $\Delta V^{\prime}$ ap alone, as shown in Figure $3 B$, simplifies the analysis. Membrane potentials produced by the new battery are given by the following equations from Linsenmeier and Steinberg (1983):

$$
\begin{aligned}
& V_{\text {ap }}=\Delta V_{\text {ap }}^{\prime}-\Delta i^{\prime}{ }_{s} R_{\text {ap }} \\
& V_{\text {ba }}=\Delta i^{\prime}{ }_{s} R_{\text {ba }}
\end{aligned}
$$

where $\Delta i_{\mathrm{s}}^{\prime}$ is the new shunt current contributed by $\Delta V_{\text {ap }}^{\prime}$ and is given by

$$
\Delta i^{\prime}{ }_{\mathrm{s}}=\Delta V^{\prime}{ }_{\mathrm{ap}} /\left(R_{\mathrm{ap}}+R_{\mathrm{s}}+R_{\mathrm{ba}}\right)
$$

Substituting the expression for $\Delta i^{\prime}$ s into Equations 5 and 6 yields

$$
\begin{aligned}
& \Delta V_{\mathrm{ap}}=\Delta V_{\mathrm{ap}}^{\prime}\left[\left(R_{\mathrm{ba}}+R_{\mathrm{s}}\right) /\left(R_{\mathrm{ap}}+R_{\mathrm{s}}+R_{\mathrm{ba}}\right)\right] \\
& \Delta V_{\mathrm{ba}}=\Delta V_{\mathrm{ap}}^{\prime}\left[R_{\mathrm{s}} /\left(R_{\mathrm{ap}}+R_{\mathrm{s}}+R_{\mathrm{ba}}\right)\right]
\end{aligned}
$$

It can be seen from Equations 8 and 9 that adding a new battery to the apical side has a greater effect on $V_{\mathrm{ap}}$ than on $V_{\mathrm{ba}}$. Thus, a change in $V_{\text {ap }}$ always leads to a smaller, shunted change in $V_{\mathrm{ba}}$ (Oakley et al., 1978), provided that the parameters $R_{\mathrm{ap}}$, $R_{\mathrm{s}}$, and $R_{\mathrm{ba}}$ are not significantly altered. Also, the resultant differences in $V_{\mathrm{ap}}$ and $V_{\mathrm{ba}}$ will always affect TEP.

\section{$\mathrm{K}^{+}$-Evoked changes in $\left[\mathrm{K}^{+}\right]_{C}$}

Increasing apical $\left[\mathrm{K}^{+}\right]_{\mathrm{o}}$ from 2 to $5 \mathrm{mM}$ depolarized $V_{\text {ap }}$ as expected since the apical membrane is permcablc to $\mathrm{K}^{+}$(Miller and Steinberg, 1977a). As shown in Figure 4, there was an 11.1 $\mathrm{mV}$ depolarization of $V_{\mathrm{ap}}$ in $8 \mathrm{~min}$. Some of the $V_{\mathrm{ap}}$ response was shunted to the basal membrane, resulting in a $7.6 \mathrm{mV}$ depolarization of $V_{\mathrm{ba}}$, and therefore a $3.5 \mathrm{mV}$ reduction in TEP.

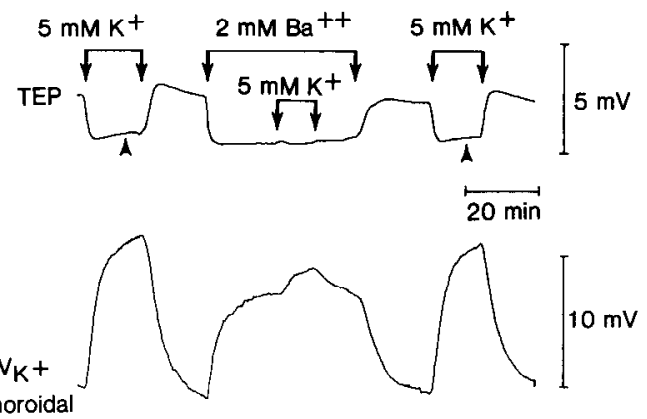

Figure 6. Effects of apical $2 \mathrm{~mm} \mathrm{Ba}^{2+}$ and increased apical $\mathrm{K}^{+}$combined. The RPE was approached from the basal side and a $\mathrm{K}^{+}$-sensitive electrode was placed in the choroid. The effect of increasing apical $\left[\mathrm{K}^{+}\right]_{0}$ on TEP and $V_{\mathrm{K}^{+}}$are shown before and after the addition of $2 \mathrm{mM} \mathrm{Ba}^{21}$ to the apical solution. Addition of $2 \mathrm{mM} \mathrm{Ba}^{2+}$ caused a decrease in TEP and a concomitant increase in $\left[\mathrm{K}^{+}\right]_{\mathrm{C}}$, as shown by $V_{\mathrm{K}^{+}}$. With the $\mathrm{Ba}^{2+}$ present, apical $\left[\mathrm{K}^{+}\right]_{0}$ was raised from 2 to $5 \mathrm{~mm}$ and back. There was a very small fluctuation in TEP and a small increase in $V_{\mathrm{K}^{+}}$. The tissue exhibited a normal response after removal of the $\mathrm{Ba}^{2+}$. Arrowheads indicate a slight recovery of TEP after apical $\left[\mathrm{K}^{+}\right]_{0}$ was increased.

When apical $\left[\mathrm{K}^{+}\right]_{\mathrm{o}}$ was returned to $2 \mathrm{mM}$, both $V_{\mathrm{ap}}$ and $V_{\mathrm{ba}}$ hyperpolarized with a resultant increase in TEP.

At the same timc, $\left[\mathrm{K}^{+}\right]_{\mathrm{C}}$ was measured by a $\mathrm{K}^{+}$-sensitive microelectrode placed in the choroid. As shown in the lower portion of Figure 4, an increase in $\left[\mathrm{K}^{+}\right]_{\mathrm{C}}$ (indicated by the increase in $V_{\mathrm{K}^{+}}$) followed the depolarization of the membranes. $V_{\mathrm{K}^{+}}$increased $6.4 \mathrm{mV}$ in $8 \mathrm{~min}$ with a somewhat slower time course than the change in $V_{\mathrm{ap}}$ and $V_{\mathrm{ba}}$. [A further apparent increase seen in $V_{\mathrm{K}^{+}}$(arrow) resulted from movement of the preparation and electrode that occurred when solutions were replenished after $8 \mathrm{~min}$.] When apical $\left[\mathrm{K}^{+}\right]_{0}$ was returned to $2 \mathrm{mM}, V_{\mathrm{K}^{+}}$ decreased as $V_{\mathrm{ap}}$ and $V_{\mathrm{ba}}$ hyperpolarized. After $V_{\mathrm{K}^{+}}$returned to the baseline (12 min after change-not shown), the $\mathrm{K}^{+}$-sensitive electrode was rapidly withdrawn into the bathing solution. This resulted in a $10.0 \mathrm{mV}$ drop in $V_{\mathrm{K}^{+}}$, corresponding to a decrease in $\mathrm{K}^{+}$concentration from 3.6 to $2 \mathrm{~mm}$. Thus, the baseline $\left[\mathrm{K}^{+}\right]_{\mathrm{C}}$ at the depth of the measurement was $3.6 \mathrm{~mm}$, and the increase caused by elevated apical $\left[\mathrm{K}^{+}\right]_{\text {。 }}$ was $1.9 \mathrm{~mm}$ (from 3.6 to 5.5 $\mathrm{mM})$. A subsequent penetration and retreat yielded a baseline $\left[\mathrm{K}^{+}\right]_{\mathrm{C}}$ of 3.85 mM. $^{2}$

There are several ways in which an increase in apical $\left[\mathrm{K}^{+}\right]_{\mathrm{o}}$ might produce an increase in $\left[\mathrm{K}^{+}\right]_{\mathrm{c}}$. Spatial buffering is an appealing hypothesis for the mechanism since the apical and basal membranes are electrically coupled and permeable to $\mathrm{K}^{+}$. However, another mechanism is transcellular active transport of $\mathrm{K}^{+}$. Several ions are actively transported across the RPE from the apical side to the choroid (Miller and Steinberg, 1977b). The best known is transport of $\mathrm{K}^{+}$by the $\mathrm{Na}^{+}, \mathrm{K}^{+}$-ATPase of the apical membrane, and it is stimulated by an increase in apical $\mathrm{K}^{+}$(Miller and Steinberg, 1977b; Miller et al., 1978; Ostwald

\footnotetext{
${ }^{2}$ We chose the $2-5$ mM range for apical $\left[\mathrm{K}^{+}\right]$for 2 reasons. First, most previous investigations of the physiological properties of isolated frog RPE-choroid utilized a bathing solution containing $2 \mathrm{mM} \mathrm{K}{ }^{+}$(Steinberg and Miller, 1979). Second, $\left[\mathrm{K}^{+}\right]_{0}$ in the subretinal space of isolated retina-RPE-choroid is about $3.2 \mathrm{~mm}$ in the dark (Oakley and Steinberg, 1982). With the onset of light, subretinal $\left[\mathrm{K}^{+}\right]_{\mathrm{o}}$ drops to as low as $1 \mathrm{~mm}$ and, in the case of long light flashes, can overshoot the baseline to as high as $4.5 \mathrm{~mm}$ with light offset. Thus, the range of light-evoked variation in subretinal $\left[\mathrm{K}^{+}\right]_{\mathrm{o}}$ ranges from 1.0 to $4.5 \mathrm{~mm}$. The amount of change in membrane potential generated by altering $\mathrm{K}^{+}$concentration is proportional to the logarithm of the ratios of the 2 concentrations. This value is 1.16 for the smaller lightevoked change (3.2-1.0 $\mathrm{mm}$ ); for the large light-evoked change (1-4.5 $\mathrm{mm}$ ), it is 1.50 ; and for the $2-5 \mathrm{~mm}$ change, it is 0.92 . The treatment we used, therefore, produced a variation in $V_{\text {ap }}$ approximately within those produced by light with the retina present. $\Lambda$ lso, since we chose $2 \mathrm{~mm}\left[\mathrm{~K}^{+}\right]_{0}$ as the baseline, the change to $5 \mathrm{~mm} \mathrm{~K} \mathrm{~K}^{+}$produced an easily measurable effect, although $5 \mathrm{~mm}$ is slightly beyond the average maximal subretinal $\left[\mathrm{K}^{+}\right]_{\mathrm{o}}$ found in isolated retina-RPE-choroid.
} 


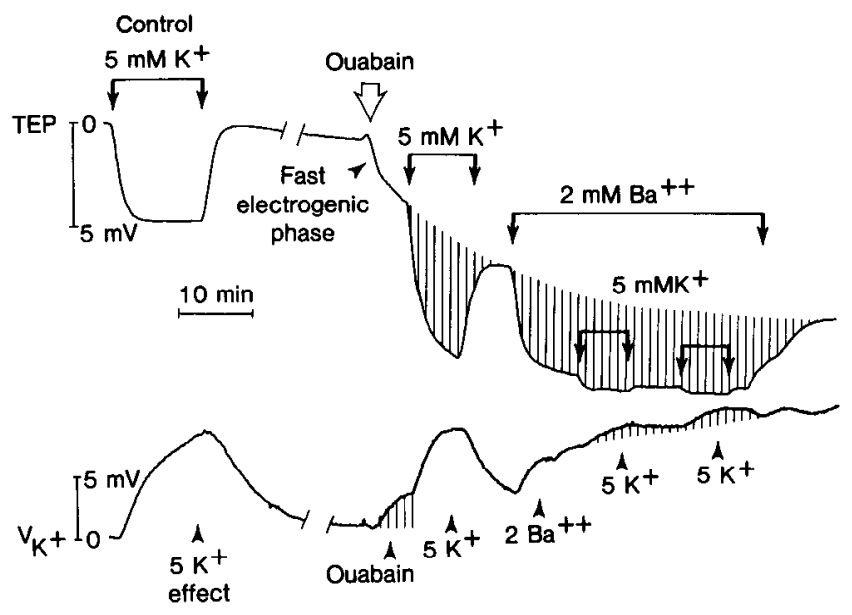

Figure 7. Effect of ouabain, $\mathrm{Ba}^{2+}$, and increased apical $\left[\mathrm{K}^{+}\right]_{0}$ on $\left[\mathrm{K}^{+}\right]_{\mathrm{C}}$. Ouabain, $0.1 \mathrm{~mm}$, in the apical solution (open arrowhead until end of trace) produced a fast decrease in TEP followed by a slower, more gradual decrease (hatching). During the fast portion of the TEP decrease, $V_{\mathrm{K}^{+}}$increased. A further increase was elicited by increasing apical $\left[\mathrm{K}^{+}\right]_{\mathrm{o}}$ from 2 to $5 \mathrm{~mm}$ and, later, by the addition of $2 \mathrm{~mm} \mathrm{Ba}^{2+}$ to the apical solution. (Compare these responses to the initial control.) Increases in apical $\left[\mathrm{K}^{+}\right]_{\mathrm{o}}$ in the presence of $\mathrm{Ba}^{2+}$ and ouabain produced only small changes in TEP and $V_{K}$.

and Steinberg, 1980). Also, the increase in $\left[\mathrm{K}^{+}\right]_{\mathrm{C}}$ could be artifactual due to leakage of $\mathrm{K}^{+}$around the cut edges of the tissue or through holes or damaged cells in the RPE. In the experiments described below, we deal with each of these alternative mechanisms, demonstrating that while each of these mechanisms may contribute to increases in $\left[\mathrm{K}^{+}\right]_{C}$ to some extent, spatial buffering is by far the principal mechanism.

\section{Changes in $\left[\mathrm{K}^{+}\right]_{C}$ due to apical $\mathrm{Ba}^{2+}$ and ouabain}

To eliminate leakage and $\mathrm{K}^{+}$-stimulated transport as a source of $\left[\mathrm{K}^{+}\right]_{\mathrm{C}}$ changes, agents other than $\mathrm{K}^{+}$were used to alter membrane potentials. $\mathrm{Ba}^{2+}$ was used in order to examine spatial buffering in the absence of apical $\mathrm{K}^{+}$conductance, ouabain to look for independence from the apical $\mathrm{Na}^{1}, \mathrm{~K}$-ATPase, and the combination of these agents in order to define the mechanism more precisely.

Our first concern was that the source of increased $\left[\mathrm{K}^{+}\right]_{\mathrm{C}}$ was simply due to artifactual $\mathrm{K}^{+}$leakage through or across the tissue. $\mathrm{Ba}^{2+}$ introduced into the apical solution depolarizes the apical membrane and blocks apical $\mathrm{K}^{+}$conductance (Griff et al., 1985). ${ }^{3}$ This depolarization is shunted to the basal membrane, leading to decreases in $V_{\text {ba }}$ and TEP. Figure 5 shows the effects of apical $2 \mathrm{mM} \mathrm{Ba}^{2+}$ and compares it with the effect of $5 \mathrm{mM}\left[\mathrm{K}^{+}\right]_{\mathrm{o}}$ in the same RPE cell. In $10 \mathrm{~min}, \mathrm{Ba}^{2+}$ depolarized $V_{\text {ap }} 13.7 \mathrm{mV}$ and $V_{\mathrm{ba}} 10.1 \mathrm{mV}$, causing a $3.6 \mathrm{mV}$ decrease in TEP. An increase in $V_{\mathrm{K}^{+}}$(in the choroid) of $2.8 \mathrm{mV}$ followed depolarization of the membranes with a somewhat slower time course. ${ }^{4}$

The $\mathrm{Ba}^{2+}$ effects were quite similar but more rapid than those produccd by $5 \mathrm{~mm}$ apical $\left[\mathrm{K}^{+}\right]_{0}$. Figurc $5 B$ shows the cffect of

\footnotetext{
${ }^{3} \mathrm{Ba}^{2+}, 1.0$ and $0.5 \mathrm{~mm}$, had the same effect on the apical membrane as $2.0 \mathrm{~mm}$ $\mathrm{Ba}^{2+}$; viz., they all depolarized $V_{\mathrm{ap}}$. However, there is some possibility that increased $\left[\mathrm{K}^{+}\right]$o may compete with $\mathrm{Ba}^{2+}$ and unblock $\mathrm{K}^{+}$conductance sites at lower $\mathrm{Ba}^{2+}$ concentrations (Armstrong and Taylor, 1980; Griff et al., 1985). We chose to use $2 \mathrm{mM} \mathrm{Ba}^{2+}$ since we would later combine increased $\left[\mathrm{K}^{+}\right]_{0}$ with it.

${ }^{4}$ The likelihood of $\mathrm{Ba}^{2+}$ increasing leakage of $\mathrm{K}^{+}$out of the basal membrane by acting to incrcasc basal $\mathrm{K}^{+}$conductance is remotc. Previous studics indicate that $\mathrm{Ba}^{2+}$ acts to block $\mathrm{K}^{+}$conductances (Armstrong and Taylor, 1980; Eaton and Brodwick, 1980; Griff et al., 1984; Oakley and Shimazaki, 1984; Sperelakis et al. 1967). (Also see this paper, Figs. 5 and 6.) Furthermore, it has been demonstrated that $\mathrm{Ba}^{2+}$ blocks apical and basal $\mathrm{K}^{+}$conductances in the frog RPE (Griff et al. 1985).
}

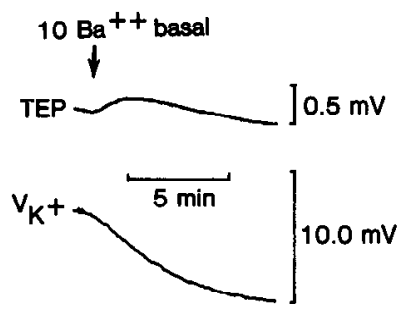

Figure 8. Effect of $10 \mathrm{~mm}$ basal $\mathrm{Ba}^{2+}$. Addition of $10 \mathrm{mM} \mathrm{Ba}^{2+}$ to the basal solution had a very small effect on TEP (note scale). However, $\left[\mathrm{K}^{+}\right]_{C}\left(V_{\mathrm{K}^{+}}\right)$decreased due to blockage of basal $\mathrm{K}^{+}$conductance even though the RPE membranes depolarized, as demonstrated by Griff et al. (1985).

$5 \mathrm{~mm}\left[\mathrm{~K}^{+}\right]_{\mathrm{o}}$ in the same cell before the addition of $\mathrm{Ba}^{2+}$. In this case, $V_{\text {ap }}$ depolarized $12.3 \mathrm{mV}$, and $V_{\text {ba }}$ depolarized $10.0 \mathrm{mV}$ (resulting in a $2.3 \mathrm{mV}$ change in TEP), while the increase in $V_{\mathrm{K}^{+}}$ was about equal to that produced by $\mathrm{Ba}^{2+}$. Note that while the 2 treatments had different effects on the magnitude of the changes in $V_{\text {ap }}$ and TEP, the effects on $V_{\mathrm{ba}}$ and $V_{\mathrm{K}^{+}}$were approximately equal. This suggests that $V_{\mathrm{ba}}$ is the determining factor and that the amount of coupling between the 2 membranes, as determined by $R_{\mathrm{s}}$, will determine the efficiency of spatial buffering. A factor that may contribute to the difference in time course may be $\mathrm{Ba}^{2+}$ blockage of apical $\mathrm{K}^{+}$conductance, changing the resistive parameters of the RPE (Griff et al., 1985).

Since $\mathrm{Ba}^{2+}$ will block apical $\mathrm{K}^{+}$conductance, an increase in apical $\left[\mathrm{K}^{+}\right]_{\mathrm{o}}$ in the presence of $\mathrm{Ba}^{2+}$ should not produce an increase in $\left[\mathrm{K}^{+}\right]_{C}$ due to $\mathrm{K}^{+}$spatial buffering. However, any artifactual $\mathrm{K}^{+}$movement across the tissue should be unaffected. We found that addition of $5 \mathrm{~mm}\left[\mathrm{~K}^{+}\right]_{0}$ in the presence of $2 \mathrm{~mm}$ apical $\mathrm{Ba}^{2+}$ caused only very small fluctuations of TEP and $V_{\mathrm{K}^{+}}$ (Fig. 6). First, we assessed the response to apical $5 \mathrm{mM}\left[\mathrm{K}^{+}\right]_{o}$ alone-a $2.0 \mathrm{mV}$ decrease in TEP and a $11.9 \mathrm{mV}$ increase in $V_{\mathrm{K}^{+}}$resulted. After recovery from $5 \mathrm{~mm}\left[\mathrm{~K}^{+}\right]_{\mathrm{o}}$, addition of $2 \mathrm{mM}$ $\mathrm{Ba}^{2+}$ reduced TEP by $2.0 \mathrm{mV}$ and increased $V_{\mathrm{K}} 7.5 \mathrm{mV}$. In the presence of $\mathrm{Ba}^{2+}$, apical $5 \mathrm{mM}\left[\mathrm{K}^{+}\right]_{\mathrm{o}}$ now resulted in only a slight decrease in TEP and a small $(2.3 \mathrm{mV})$ increase in $V_{\mathrm{K}^{+}}$. After removal of $5 \mathrm{mM}\left[\mathrm{K}^{+}\right]_{0}$ and $\mathrm{Ba}^{2+}$, TEP and $V_{\mathrm{K}^{+}}$recovered completely. Increasing apical $\left[\mathrm{K}^{+}\right]_{0}$ to $5 \mathrm{~mm}$ after this recovery resulted in changes of TEP and $V_{\mathrm{K}^{+}}$that were approximately the same as those in the initial test.

In experiments where apical [ $\left.\mathrm{K}^{\prime}\right]_{0}$ was raised in the presence of $\mathrm{Ba}^{2+}$, there was a small increase in $V_{\mathrm{K}^{+}}$and a slight decrease in TEP. At the concentrations of $\mathrm{Ba}^{2+}$ used, $\mathrm{K}^{+}$permeability was completely blocked when apical $\left[\mathrm{K}^{+}\right]_{\text {。 }}$ was $5 \mathrm{~mm}$ or less (Griff et al., 1985); therefore, there should have been no passive entry of $\mathrm{K}^{+}$into the cell to depolarize $V_{\text {ap }}$ and reduce TEP. The slight change in TEP could be due to electrogenic transport of $\mathrm{K}^{+}$or to its movement through an ion-specific conductance in the paracellular pathway. (Nonspecific leakage would not be expected to alter TEP.)

In order to test specifically for a contribution to $\mathrm{K}^{+}$movement by the apical $\mathrm{Na}^{+}, \mathrm{K}^{+}$-ATPase (pump), we applied ouabain to the apical side. The action of ouabain on the RPE has been previously characterized (Miller and Steinberg, 1977b; Miller et al., 1978). Apical ouabain depolarizes $V_{\text {ap }}$ in 2 phases. There is an initial fast phasc arising from the loss of the elcctrogenic contribution of the pump to $V_{\text {ap }}$ that lasts for about $2.5 \mathrm{~min}$ and that has an average depolarization of about $9-10 \mathrm{mV}$. The subsequent slow phase is caused by the gradual abatement of the intracellular ionic gradients and persists for hours at an average rate of $0.4 \mathrm{mV} / \mathrm{min}$ (Miller et al., 1978).

Figure 7 depicts the results of adding $0.1 \mathrm{~mm}$ ouabain to the apical side of the RPE. The first portion of the trace shows the response of TEP and $V_{\mathrm{K}^{+}}$to $5 \mathrm{mM}\left[\mathrm{K}^{+}\right]_{\mathrm{o}}$ before ouabain; TEP decreased $4.8 \mathrm{mV}$, while $V_{\mathrm{K}^{+}}$increased $8.2 \mathrm{mV}$. The subsequent 


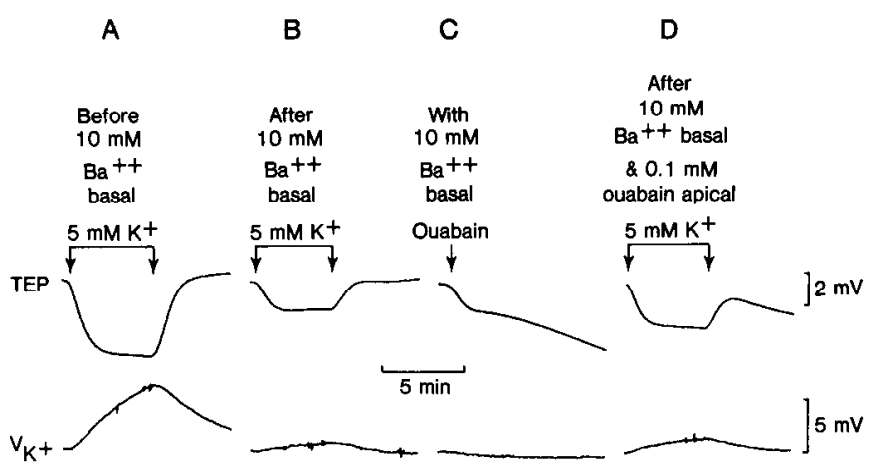

Figure 9. Effects of increasing apical $\left[\mathrm{K}^{+}\right]_{0}$ in the presence of $10 \mathrm{~mm}$ basal $\mathrm{Ba}^{2+}$ and $0.1 \mathrm{~mm}$ ouabain. $A$, Apical $\left[\mathrm{K}^{+}\right]$, was increased from 2 to $5 \mathrm{~mm}$ before the addition of $10 \mathrm{~mm} \mathrm{Ba}{ }^{2+}$. TEP decreased and $\left[\mathrm{K}^{+}\right]_{C}$ increased as expected. $B$, After the addition of $10 \mathrm{~mm}$ basal $\mathrm{Ba}^{2+}$, the increase in $\left[\mathrm{K}^{+}\right]_{\mathrm{C}}$ elicited by increased apical $\left[\mathrm{K}^{+}\right]_{\mathrm{o}}$ was greatly reduced. However, a small residual $\left[\mathrm{K}^{+}\right]_{\mathrm{C}}$ response remained. $C$, When $0.1 \mathrm{~mm}$ ouabain was added to the apical solution, TEP decreased, at first rapidly and then gradually, as expected due to depolarization of the apical membrane. This depolarization in the presence of $10 \mathrm{~mm}$ basal $\mathrm{Ba}^{2+}$ produced no noticeable change in $\left[\mathrm{K}^{+}\right]_{\mathrm{C}}\left(V_{\mathrm{K}^{+}}\right)$, unlike the effects of ouabain in the absence of $\mathrm{Ba}^{2+}$ (see Fig. 7). $D$, Apical $\left[\mathrm{K}^{+}\right]$was increased from 2 to $5 \mathrm{~mm}$ after the addition of ouabain and in the presence of 10 $\mathrm{mM} \mathrm{Ba}^{2+}$. The small residual response still remained, indicating that the electrode had not moved out of the choroid between the experiments.

addition of ouabain rapidly reduced TEP, corresponding to the initial fast phase in the depolarization in $V_{\mathrm{ba}}$. During this time $V_{\mathrm{K}^{+}}$increased $2.0 \mathrm{mV}$. After a few minutes, the fast phase had ended, indicated by the shallower decline in TEP. When $5 \mathrm{~mm}$ $\left[\mathrm{K}^{+}\right]$, was then added to the apical side, TEP was reduced as the membranes were depolarized and $V_{\mathrm{K}^{+}}$increased $4.6 \mathrm{mV}$. With the slow decline in TEP (indicated by the cross-hatching), $V_{\mathrm{K}^{+}}$ also continued to drift upward. When $2 \mathrm{~mm}$ apical $\mathrm{Ba}^{2+}$ was added, TEP and $V_{\mathrm{K}^{+}}$behaved in the same manner as in the absence of ouabain; i.e., TEP decreased $(5.0 \mathrm{mV})$ and $V_{\mathrm{K}^{+}}$increased $(2.5 \mathrm{mV})$. Later, in the presence of ouabain and $2 \mathrm{mM}$ $\mathrm{Ba}^{2+}, 5 \mathrm{mM} \mathrm{K}^{+}$was again introduced (and removed) twice, producing discernible flucluations in TEP and $V_{\mathrm{K}^{+}}$.

To summarize, we produced an increase in $\left[\mathrm{K}^{+}\right]_{\mathrm{C}}$ using 3 different mechanisms to depolarize RPE membrane; viz., deletion of the electrogenic pump (fast ouabain phase), increasing apical $\left[\mathrm{K}^{+}\right]_{\mathrm{o}}$, and elimination of apical $\mathrm{K}^{+}$conductance with $\mathrm{Ba}^{2+}$. Therefore, leakage and the pump are eliminated as major sources of $\mathrm{K}^{+}$movement across the tissue under our experimental conditions. The small $\left[\mathrm{K}^{+}\right]_{c}$ increase seen with the pump poisoned in the presence of $\mathrm{Ba}^{2+}$ is probably due to leakage or to nonouabain-sensitive $\mathrm{K}^{+}$transport.

Effect of basal $\mathrm{Ba}^{2+}$ on $\left[\mathrm{K}^{+}\right]_{C}$

The spatial buffering hypothesis relies on efflux of $\mathrm{K}^{+}$through the basal membrane, which is known to have a $\mathrm{K}^{+}$conductance (Miller and Steinberg, 1977a). To demonstrate that this, rather than another carrier, is the major routc for basal $\mathrm{K}^{+}$cfflux, wc sought to block basal $\mathrm{K}^{+}$conductance with $\mathrm{Ba}^{2+}$. High concentrations $\left(5-10 \mathrm{~mm}\right.$ ) of $\mathrm{Ba}^{2+}$ in the basal bath will block basal $\mathrm{K}^{+}$ conductance and depolarize the basal membrane (Griff et al., 1985 ). When a solution containing $10 \mathrm{mM} \mathrm{Ba}^{2+}$ was added to the basal side, an initial increase in TEP occurred (due to the depolarization of $V_{\mathrm{ba}}$ ) concomitant with a decline in $V_{\mathrm{K}^{+}}$of 6.6 $\mathrm{mV}$ (Fig. 8). ${ }^{5}$ This represents a decrease in $\left[\mathrm{K}^{+}\right]_{c}$ from 2.8 to $1.9 \mathrm{~mm}$ (using the average value of $\left[\mathrm{K}^{+}\right]_{\mathrm{C}}$ as the starting point), which is about the concentration of $\mathrm{K}^{+}$in the bathing solution.

\footnotetext{
${ }^{5}$ The subsequent reduction in TEP is probably due to the effect of $\mathrm{Ba}^{2+}$ on the apical membrane (see Griff et al., 1985).
}

Thus, blocking basal $\mathrm{K}^{+}$conductance decreases $\left[\mathrm{K}^{+}\right]_{\mathrm{C}}$ even though RPE membranes depolarize.

Ouabain was later added to the apical side to depolarize the RPE in order to test for inhibition of evoked basal $\mathrm{K}^{+}$efflux in the presence of basal $\mathrm{Ba}^{2+}$. As shown in Figure $9 C, 0.1 \mathrm{mM}$ ouabain produced the expected 2-phase change in TEP. However, instead of a large efflux of $\mathrm{K}^{+}$(as seen without basal $\mathrm{Ba}^{2+}$ ), there was very little change in $\left[\mathrm{K}^{+}\right]_{\mathrm{C}}$ (actually a very slight decrease).

Finally, to show that the $\mathrm{K}^{+}$-sensitive microelectrode had not moved appreciably during the experiment, apical $\mathrm{K}^{+}$was changed from 2 to $5 \mathrm{~mm}$ at the beginning of the experiment, after the addition of $\mathrm{Ba}^{2+}$, and again after the addition of ouabain. Figure 9, $A$ (before $\mathrm{Ba}^{2+}$ ) and $B$ (after $\mathrm{Ba}^{2+}$ ), shows that the addition of $10 \mathrm{mM} \mathrm{Ba}^{2+}$ reduced the magnitude of the TEP change due to increased apical $\mathrm{K}^{+}$. This was due to $\mathrm{Ba}^{2+}$ inhibition of part of the apical $\mathrm{K}^{+}$conductance (Griff et al., 1985). A small increase in $V_{\mathrm{K}^{+}}$still occurred that may be due to leakage or $\mathrm{K}^{+}$transport. After the addition of ouabain, in the presence of basal $\mathrm{Ba}^{2+}$, the small increase in $V_{\mathrm{K}^{+}}$was still evoked by an increase in apical $\left[\mathrm{K}^{+}\right]_{0}$, indicating that the electrode had not moved out of the choroid (Fig. 9D). In summary, basal $\mathrm{Ba}^{2+}$ blocks $\mathrm{K}^{+}$efflux such that increases in $\left[\mathrm{K}^{+}\right]_{\mathrm{C}}$ caused by depolarizing agents are greatly reduced or abolished.

\section{Discussion}

The spatial buffering hypothesis requires $\mathrm{K}^{+}$efflux from the basal mcmbranc to bc a function of $V_{\mathrm{ba}}$, such that (1) an increase in apical $\left[\mathrm{K}^{+}\right]_{0}$ decreases the outward chemical driving force on RPE cell $\left[\mathrm{K}^{+}\right]_{\mathrm{i}}$, reducing $V_{\mathrm{ap}}$ so that the electrical and chemical driving forces become equal; (2) the change in $V_{\text {ap }}$ propagates to the basal membrane, where it reduces $V_{\mathrm{ba}}$; and (3) since $\left[\mathrm{K}^{+}\right]_{\mathrm{C}}$ is unchanged, the basal electrical driving force is less than the outward chemical driving force, and $\mathrm{K}^{+}$efflux from the basal membrane increases.

We can now summarize the evidence for $\mathrm{K}^{+}$spatial buffering in the isolated RPE. First, depolarization of RPE membranes produces basal $\mathrm{K}^{+}$efflux. This was demonstrated by increasing apical $\left[\mathrm{K}^{+}\right]_{\mathrm{o}}$ or applying apical $\mathrm{Ba}^{2+}$. Both of these treatments depolarize RPE membranes and lead to efflux of $\mathrm{K}^{+}$from the basal membrane, the latter without the imposition of a transepithelial $\mathrm{K}^{+}$gradient. Also, depolarization of RPE membranes by inhibition of pump activity produces an efflux of $\mathrm{K}^{+}$from the basal membrane in accordance with the degree of membrane depolarization in both the rapid, electrogenic phase and slower, "rundown" phase. Second, we can eliminate transepithelial $\mathrm{K}^{+}$ leakage as a source since a change in apical $\mathrm{K}^{+}$is not a necessary condition for the effect. Third, the effect does not require operation of the $\mathrm{Na}^{+}, \mathrm{K}^{+}$-ATPase, and, under conditions designed to reveal other $\mathrm{K}^{+}$-stimulated transport (i.e., apical $\mathrm{Ba}^{2+}$ plus ouabain), increased apical $\left[\mathrm{K}^{+}\right]_{\text {o }}$ produces only a small efflux of $\mathrm{K}^{+}$from the basal membrane. On the basis of these data, we conclude that depolarization of the basal membrane is the determining factor in the experimentally induced $\mathrm{K}^{+}$efflux from the basal membrane.

The following discussion describes a model of how $\mathrm{K}^{+}$spatial buffering may work in the RPE. In this model we assume that the apical and basal compartments are infinite in volume, that intracellular $\mathrm{K}^{+}$is kept constant by an active pump mechanism, and that the apical and basal membranes are well coupled so that $R_{\mathrm{s}}$ approaches 0 , but the shunt is impermeable to $\mathrm{K}^{+}$. The net $\mathrm{K}^{+}$flux through the membranes can be described as an electrical current $\left(I_{\mathrm{K}}\right)$ flowing across a specific membrane conductance $\left(g_{\mathrm{K}}\right)$ generated by the driving potential on $\mathrm{K}^{+}\left(D_{\mathrm{K}}\right)$. Using Ohm's law and converting current to moles $\mathrm{K}^{+}$flux, we find

$$
\mathrm{K}^{+} \text {flux }=I_{\mathrm{K}} / F=g_{\mathrm{K}} D_{\mathrm{K}} / F
$$


where $F$ is the Faraday constant. The driving potential, $D_{\mathrm{K}}$, is the difference between the membrane potential $\left(E_{\mathrm{m}}\right)$ and the $\mathrm{K}^{+}$ equilibrium potential $\left(E_{\mathrm{K}}\right)$ as defined by the Nernst equation.

In the limiting case where (1) both membranes are permeable only to $\mathrm{K}^{+},(2)$ apical and basal membranes have equal $\mathrm{K}^{+}$ permeability, and (3) the extracellular $\left[\mathrm{K}^{+}\right]_{\mathrm{o}}$ is equal on both sides (and intracellular $\left[\mathrm{K}^{+}\right]_{\mathrm{i}}$ is held constant), the net $\mathrm{K}^{+}$flux will be 0 in the steady state, since $E_{\mathrm{m}}$ is equal to $E_{\mathrm{K}}$. With the same environment on both sides, the membrane potentials ( $V_{\mathrm{ap}}$ and $V_{\text {ba }}$ ) will also be equal. Thus, for both membranes,

$$
\mathrm{K}^{+} \text {flux }=g_{\mathrm{K}}\left(E_{\mathrm{m}}-E_{\mathrm{K}}\right) / F=0
$$

Now, when $\left[\mathrm{K}^{+}\right]_{\mathrm{o}}$ is raised on the apical side, the apical membrane potential should depolarize by some value, $\Delta V_{\mathrm{ap}}$, reflecting the new value of $E_{\mathrm{K}}$. However, since the membranes are well coupled, the apical and basal membrane potentials ( $V_{\text {ap }}$ and $\left.V_{\mathrm{ba}}\right)$ will contribute to each other; $V_{\mathrm{ba}}$ will tend to hyperpolarize $V_{\mathrm{ap}}$, moving it away from the apical $\mathrm{K}^{+}$equilibrium potential; $V_{\mathrm{ap}}$, on the other hand, will tend to depolarize $V_{\mathrm{ba}}$ away from the basal $\mathrm{K}^{+}$equilibrium potential. Since both membranes contribute equally, the net effect will be that each membrane potential will deviate from its respective $\mathrm{K}^{+}$equilibrium potential by $1 / 2 \Delta V_{\mathrm{ap}} . \mathrm{A} \mathrm{K} \mathrm{K}^{+}$driving force is created on each membrane, producing net fluxes of $\mathrm{K}^{+}$such that

$$
\begin{gathered}
\text { apical } \mathrm{K}^{+} \text {flux }=g_{\mathrm{K}}\left[\left(V_{\mathrm{ap}}-1 / 2 \Delta V_{\mathrm{ap}}\right)-E_{\mathrm{K}} \text { apical }\right] / F=\text { influx }( \\
\text { basal } \mathrm{K}^{+} \text {flux }=g_{\mathrm{K}}\left[\left(V_{\mathrm{ba}}+1 / 2 \Delta V_{\mathrm{ap}}\right)-E_{\mathrm{K}} \text { basal }\right] / F=\text { efflux }
\end{gathered}
$$

Thus, an influx of $\mathrm{K}^{+}$is produced at the apical membrane, an efflux of $\mathrm{K}^{+}$at the basal membrane, and a net $\mathrm{K}^{+}$flux across the tissue translates $\mathrm{K}^{+}$from the apical to the basal compartment. Spatial buffering is then strictly a function of RPE membrane potentials and apical/basal coupling in this model, and it could operate in either direction.

How do the RPE and the model compare? Since the magnitude of the basal efflux is determined by the change in $V_{\mathrm{ba}}$, the efficiency of spatial buffering is controlled, in part, by the value of $R_{\mathrm{s}}$; i.e., a low shunt resistance means greater spatial buffering, and vice versa (Equation 9). In the RPE the 2 compartments are isolated by a high-resistance barrier where the shunt resistance is about 10 times the apical plus the basal resistance (Miller and Steinberg, 1977a). Thus, a large value of $R_{\mathrm{s}}$ attenuates the signal propagated from one membrane to the other (recall Equations 8 and 9). In addition, if the paracellular pathway were highly permeable to $\mathrm{K}^{+}$, then the compartments would be less well isolated. In our preparation, the shunt is more permeable to $\mathrm{Na}^{+}$than to $\mathrm{K}^{+}$, so that the compartments are well isolated with respect to $\mathrm{K}^{+}$(Miller and Steinberg, 1977a). Thus, while the shunt resistance allows membrane potential changes to propagate from one membrane to the other (moving $\mathrm{K}^{+}$between compartments via the RPE cells), selectivity of the paracellular pathway impedes extracellular movement of $\mathrm{K}^{+}$between compartments.

Other factors will influence RPE spatial buffering in our preparation. First, Miller and Steinberg (1977a) found that $\mathrm{K}^{+}$conductance accounts for only $52 \%$ of the total apical conductance; therefore, the apical membrane potential does not entirely reflect apical $E_{\mathrm{K}}$, and changes in apical $\left[\mathrm{K}^{+}\right]_{\mathrm{o}}$ will have an attenuated effect on $V_{\text {ap }}$. [The basal membrane is a better $\mathrm{K}^{+}$electrode since $\mathrm{K}^{+}$conductance accounts for $90 \%$ of the total (Miller and Steinberg, 1977a).] Second, membrane $\mathrm{K}^{+}$conductance may change with membrane potential. Many types of potassium channels are known to be voltage sensitive, most commonly increasing conductance with depolarization (Latorre and Miller, 1983). Changes in $g_{\mathrm{K}}$ would alter the magnitude of $\mathrm{K}^{+}$flux across the affected membrane but would not affect the direction of the flux induced by spatial buffering. Thus, in the case of most characterized $\mathrm{K}^{+}$channels, the rate of efflux from the basal mem- brane produced by depolarization would be larger than that predicted by the Ohmic model, since $g_{\mathrm{K}}$ would change (Equations 12 and 13). A third factor to consider is the degree to which the choroid acts as an unstirred layer since diffusion out of the choroid will affect spatial buffering. $\left[\mathrm{K}^{+}\right]_{\mathrm{C}}$ is higher than the basal bath $(2.8$ vs $2.0 \mathrm{~mm})$, presumably because of the unstirred layer effect, and it increases when basal $\mathrm{K}^{+}$efflux increases. However, the choroid permits $\mathrm{K}^{+}$efflux into the basal bath when $\left[\mathrm{K}^{+}\right]_{\mathrm{C}}$ increases. We expect that more efficient removal of choroidal $\mathrm{K}^{+}$would increase the efficiency of spatial buffering. Thus, in vivo, the large choroidal blood supply may serve to remove $\left[\mathrm{K}^{\prime}\right]_{\mathrm{C}}$ that builds up, maintaining efficiency of the $\mathrm{K}^{+}$removal mechanism. Finally, while other factors such as modulation of the apical $\mathrm{Na}^{+}, \mathrm{K}^{+}$-ATPase (Griff et al., 1985) and changes in intracellular $\left[\mathrm{K}^{+}\right]_{\mathrm{i}}$ (Oakley et al., 1978) may have effects on $\mathrm{K}^{+}$flux, membrane potential changes, such as those produced by variations in $\left[\mathrm{K}^{+}\right]_{0}$, are probably the primary determinants of the direction of net change in RPE basal $\mathrm{K}^{+}$flux.

Changes in $\left[\mathrm{K}^{+}\right]_{\mathrm{C}}$ in vivo may be different from those observed in our experimental system. Some animals such as cat (Steinberg et al., 1978), gecko, and chick (unpublished observations) have choroids that are much more impermeable than that of frog. A consequence of this may be a buildup of $\left[\mathrm{K}^{+}\right]_{C}$ in the region of Bruch's membrane if circulating blood removes $\mathrm{K}^{+}$relatively slowly. Changes in $\left[\mathrm{K}^{+}\right]_{\mathrm{C}}$ could have an effect on TEP in these animals by depolarizing $V_{\text {ba }}$. On the other hand, as suggested above, changes in $\left[\mathrm{K}^{+}\right]_{C}$ in vivo may be relatively insignificant since the vessels of the choriocapillaris possess large fenestrae that allow rapid equilibration of $\mathrm{K}^{+}$changes through free diffusion of solutes from the choroid to the blood (Alm, 1983).

TEP changes in our in vitro system produced by stepwise increases in apical $\left[\mathrm{K}^{+}\right]_{\circ}$ often showed delayed effects that seemed to parallel the changes in $\left[\mathrm{K}^{+}\right]_{\mathrm{C}}$. The control responses in Figure 6 are examples of this. In the first portion of the trace in Figure 6 , TEP falls rapidly following the addition of $5 \mathrm{~mm}$ apical $\left[\mathrm{K}^{+}\right]_{0}$, while changes in $V_{\mathrm{K}^{+}}$lag somewhat behind changes in TEP. During the slow rise to the peak in $V_{\mathrm{K}^{+}}$there is a slight delayed recovery of TEP (arrowheads). Removal of $5 \mathrm{~mm}$ apical $\left[\mathrm{K}^{+}\right]_{0}$ (a change in $\mathrm{K}^{+}$similar to that seen during light stimulation of the retina) produces a rapid rise in TEP that overshoots the baseline with a delayed recovery. $V_{\mathrm{K}}$ also recovers but at a slower rate. As $V_{\mathrm{K}^{+}}$nears the original baseline, TEP also approaches the baseline. These delayed effects could be more pronounced in other animals where the physical properties of the choroid greatly retard diffusion of $\mathrm{K}^{+}$away from the basal membrane, permitting an even larger buildup of $\left[\mathrm{K}^{+}\right]_{\mathrm{C}}$.

For the modulation of $\left[\mathrm{K}^{+}\right]_{\mathrm{o}}$ in the subretinal space, the significance of $\mathrm{K}^{+}$spatial buffering by the RPE must be considered in light of other mechanisms. First, there is strong evidence that variation in the rate of photoreceptor $\mathrm{Na}^{+} / \mathrm{K}^{+}$pump activity is a major source of the recovery from light-evoked $\left[\mathrm{K}^{+}\right]_{0}$ changes (Oakley, 1983; Shimazaki and Oakley, 1984; Steinberg et al., 1980). Second, Müller cell processes extend to midway along the photoreceptor inner segment, and these cells have been proposed as $\mathrm{K}^{+}$spatial buffers on the basis of their anatomical characteristics and physiological experiments (Karwoski and Proenza, 1980; Newman, 1984; Newman and Odette, 1984; Newman et al., 1984). However, Shimazaki and Oakley (1984), in experiments designed to eliminate the effect of Müller cell spatial buffering, found that $\mathrm{K}^{+}$reaccumulation in the subretinal space of isolated retinas (without the RPE) may proceed by the photoreceptor pump mechanism alone, although the methods they used do not completely rule out participation by Müller cells (Newman, 1985; Shimazaki and Oakley, 1984). Both of these mechanisms would operate at the level of the inner segment, while $\mathrm{K}^{+}$that diffuses distally away from this region will be in closer proximity to the RPE apical processes, which occupy much of the space between the photoreceptor outer segments. 
The RPE then could cooperate with other mechanisms for control of subretinal $\left[\mathrm{K}^{+}\right]_{\mathrm{o}}$ from the inner segment to the RPE apical border. Accurate measurement of choroidal $\mathrm{K}^{+}$fluxes during light-evoked $\mathrm{K}^{+}$changes and recovery are needed to determine the relative contribution of the RPE to modulation of subretinal $\left[\mathrm{K}^{+}\right]_{\text {. }}$.

Note added in proof: While this paper was in press, results from a somewhat different analysis of this problem were published (LaCour et al., 1986).

\section{References}

Alm, A. (1983) Microcirculation of the eye. In The Physiology and Pharmacology of the Microcirculation, Vol. 1, N. A. Mortillaro, ed., pp. 299-359, Academic, New York.

Armstrong, C. M., and S. R. Taylor (1980) Interaction of barium ions with potassium channels in squid giant axons. Biophys. J. 30:473488.

Boulpaep, E. L. (1971) Electrophysiological properties of the proximal tubule: Importance of cellular and intracellular pathways. In Electrophysiology of Epithelia, G. Giebisch, ed., Schattauer Verlag, Stuttgart.

Coles, J. A., and R. K. Orkand (1983) Modification of potassium movement through the retina of the drone (Apis mellifera) by glial uptake. J. Physiol. (Lond.) 340: 157-174.

Eaton, D. C., and M. S. Brodwick (1980) Effects of barium on the potassium conductance of squid axon. J. Gen. Physiol. 75: 727-750.

Frankenhaeuser, B., and A. L. Hodgkin (1956) After-effects of impulses in the giant fibers of Loligo. J. Physiol. (Lond.) 131: 341-376.

Gardner-Medwin, A. R. (1982) A study of the mechanism by which potassium moves through brain tissue in the rat. J. Physiol. (Lond.) 340: $157-174$.

Griff, E. R., and R. H. Steinberg (1984) Changes in apical [ $\left.\mathrm{K}^{+}\right]$produce delayed basal membrane responses of the retinal pigment epithelium in gecko. J. Gen. Physiol. 83: 193-211.

Griff, E. R., Y. Shirao, and R. H. Steinberg (1984) Light-evoked slowing of RPE $\mathrm{Na}^{+}-\mathrm{K}^{+}$pump unmasked by barium. Invest. Ophthalmol. Vis. Sci. [Suppl.] 25: 289.

Griff, E. R., Y. Shirao, and R. H. Steinberg (1985) Ba $^{2+}$ unmasks K ${ }^{+}$ modulation of the $\mathrm{Na}^{+}-\mathrm{K}^{+}$pump in the frog retinal pigment epithelium. J. Gen. Physiol. 86: 853-876.

Hughes, B. A., S. S. Miller, and T. E. Machen (1984) Effects of cyclic AMP on fluid absorption and ion transport across frog pigment epithelium: Measurements in the open circuit state. J. Gen. Physiol. 83 . 875-899.

Karwoski, C. J., and L. M. Proenza (1980) Neurons, potassium, and glia in proximal retina of Necturus. J. Gen. Physiol. 75: 141-162.

Kuffler, S. W. (1967) Neuroglial cells: Physiological properties and a potassium mediated cffect of ncuronal activity on the glial membrane potential. Proc. R. Soc. Lond. [Biol.] 168: 1-21.

LaCour, M., H. Lund-Andersen, and T. Zeuthen (1986) Potassium transport of the frog retinal pigment epithelium: Autoregulation of potassium activity in the subretinal space. J. Physiol. 375: 461-479.

Latorre, R., and C. Miller (1983) Conduction and selectivity in potassium channels. J. Membr. Biol. 71: 11-30.

Linsenmeier, R. A., and R. H. Steinberg (1982) Origin and sensitivity of the light peak of the intact cat eye. J. Physiol. (Lond.) 331: 653673.

Linsenmeier, R. A., and R. H. Steinberg (1983) A light-evoked interaction of the apical and basal membranes of the retinal pigment epithelium: The c-wave and the light peak. J. Neurophysiol. 50:136147.

Miller, S. S., and R. H. Steinberg (1977a) Passive ionic properties of frog retinal pigment epithelium. J. Membr. Biol. 36: 337-372.
Miller, S. S., and R. II. Steinberg (1977b) Active transport of ions across frog retinal pigment epithelium. Exp. Eye Res. 25: 235-248.

Miller, S. S., and R. H. Steinberg (1982) Potassium transport across the frog retinal pigment epithelium. J. Membr. Biol. 67: 199-209.

Miller, S. S., R. H. Steinberg, and B. Oakley II (1978) The electrogenic sodium pump of the frog retinal pigment epithelium. J. Membr. Biol. 44: $259-279$.

Newman, E. A. (1984) Regional specialization of retinal glial cell membranes. Nature 309: 155-157.

Newman, E. A. (1985) $\mathrm{Ca}^{2+}$-activated $\mathrm{K}^{+}$current in retinal Müller cells. Invest. Ophthalmol. Vis. Sci. [Suppl.] 26: 312.

Newman, E. A., and L. L. Odette (1984) Model of electroretinogram b-wave generation: A test of the $\mathrm{K}^{+}$hypothesis. J. Neurophysiol. 51: 164-182.

Newman, E. A., D. A. Frambach, and L. L. Odette (1984) Control of extracellular potassium levels by glial cell $\mathrm{K}^{+}$siphoning. Science 225 : 1174-1175.

Oakley, B. II (1977) Potassium and the photoreceptor-dependent pigment epithelium hyperpolarization. J. Gen. Physiol. 70: 405-425.

Oakley, B. II (1983) Effects of maintained illumination upon $\left[\mathrm{K}^{+}\right]$in the subretinal space of isolated retina of toad. Vision Res. 23: 13251337.

Oakley, B. II, and H. Shimazaki (1984) Differential effects of blocking potassium conductance upon ERG b-wave and slow PIII. Soc. Neurosci. Abstr. 10: 325.

Oakley, B. II, and R. H. Steinberg (1982) Effects of maintained illumination upon $\left[\mathrm{K}^{+}\right]_{0}$ in the subretinal space of the frog retina. Vision Res. 22: 767-773.

Oaklcy, B. II, R. H. Steinberg, S. S. Miller, and S. E. Nilsson (1977) The in vitro frog pigment epithelial cell hyperpolarization in response to light. Invest. Ophthalmol. Vis. Sci. 16: 771-774.

Oakley, B. II, S. S. Miller, and R. H. Steinberg (1978) Effect of intracellular potassium upon the electrogenic pump of frog retinal pigment epithelium. J. Membr. Biol. 44: 281-307.

Orkand, R. K., J. G. Nichols, and S. W. Kuffler (1966) Effect of nerve impulses on the membrane potential of glial cells in the central nervous system. J. Neurophysiol. 29: 788-806.

Ostwald, T. J., and R. H. Steinberg (1980) Localization of the frog retinal pigment epithelium $\mathrm{Na}^{+}-\mathrm{K}^{+}$ATPase. Exp. Eye Res. 31: 351360 .

Shimazaki, H., and B. Oakley II (1984) Reaccumulation of $\left[\mathrm{K}^{+}\right]_{\mathrm{o}}$ in the toad retina during maintained illumination. J. Gen. Physiol. 84: $475-504$.

Somjen, G. G. (1979) Extracellular potassium in the mammalian central nervous system. Annu. Rev. Physiol. 41: 159-177.

Sperelakis, N. R., M. F. Schneider, and E. J. Harris (1967) Decreased $\mathrm{K}^{+}$conductance produced by $\mathrm{Ba}^{++}$in frog sartorius fibres. J. Gen. Physiol. 50: 1565-1583.

Steinberg, R. H., and S. S. Miller (1979) Transport and membrane properties of the retinal pigment epithelium. In The Retinal Pigment Epithelium, K. M. Zinn and M. F. Marmor, eds., pp. 205-225, Harvard U. P., Cambridge, MA.

Steinberg, R. H., S. S. Miller, and W. H. Stern (1978) Initial observations on the isolated retinal pigment epithelium-choroid of the cat. Invest. Ophthalmol. Vis. Sci. 17: 675-678.

Steinberg, R. H., B. Oakley II, and G. Neimeyer (1980) Light-evoked changes in $\left[\mathrm{K}^{+}\right]_{0}$ in retina of intact cat cyc. J. Ncurophysiol, 44: 897921 .

Walker, J. L. (1971) Ion specific liquid ion exchanger microelectrodes. Anal. Chem. 43: 89A-93A. 